\title{
High-dose radioiodine outpatient therapy
}

\author{
Radioiodoterapia ambulatorial de alta dose
}

Laura Sterian Ward'

$\mathrm{T}$ he number of patients who need radioiodine therapy (RIT) after surgical excision of thyroid tumors has been rising in Brazil, as well as the number of differentiated thyroid carcinomas detected by ultrasonography. Likewise most international guidelines, the consensus on thyroid cancer from the Department of Thyroid of the Sociedade Brasileira de Endocrinologia \& Metabologia (Brazilian Society of Endocrinology and Metabolism, SBEM) recommends radioiodine remnant ablation to all patients submitted to a total thyroidectomy, with the exception of a very-lowrisk patient (TINOM0, with single tumor completely excised) (1). The rationale is to destroy any remaining tumor and to improve the ease of follow-up by eliminating all follicular cells, thereby making serum thyroglobulin $(\mathrm{Tg})$ dosage a more specific marker of recurrent or persistent disease. The procedure is not mandatory in patients categorized as low risk and very low risk and can be accomplished, in some instances, by a single ${ }^{131} \mathrm{I}$ dose of $30 \mathrm{mCi}$ (equivalent to $1100 \mathrm{Mbq}$ ), which delivers about 10 whole-body rads to the patient, although most endocrinologists prefer to administer a dose of $100 \mathrm{mCi}$. Brazilian regulations impose the hospitalization of all patients treated with doses higher than $30 \mathrm{mCi}$; however, unfortunately, the number of facilities enabled to administrate high-dose radioiodine has not increased in the same proportion of the cases in need of these doses, and the limited number of available ward beds has aggravated the patients' troubles. Because we usually withhold thyroid hormone therapy, waiting for the radioiodine ablation of thyroid remnants after surgery, many patients have remained hypothyroid for much longer than the expected four to six weeks necessary to elevate their serum TSH levels (1). Also, withdrawal of thyroid hormone has been the standard procedure over the last decades to increase $\mathrm{TSH}$, thereby enhancing the sensitivity of $\mathrm{Tg}$ measurement and increasing radioiodine uptake by recurrent thyroid tumors (1). Hence, high-risk patients submitted to control whole-body scans frequently have to endure the ordeal of hypothyroidism and the risk of tumor cell stimulation due to elevated TSH levels, which many times takes much longer than expected.

The publication of Sapienza and cols. (2), demonstrating the feasibility of highdose radioiodine outpatient therapy, holds out hopes for a new scenario for Brazilian patients. The authors did not detect any significant environmental impact of the administration of 100 to $150 \mathrm{mCi}$ of ${ }^{131} \mathrm{I}$ to 20 outpatients. They monitored 27 family caregiver members, who were given personal dosimeters and were asked not to modify their common routine. In 26 out of these individuals, the dose of ${ }^{131}$ I received was lower than $1 \mathrm{mSv}$ during the observation period. Even the one individual, who disobeying the medical recommendations, remained close to the patient for a long time, received a dose of ${ }^{131} \mathrm{I}(2,8 \mathrm{mSv})$ that did not exceed the $5,0 \mathrm{mSv}$ value considered acceptable for caregivers (2). Although we need to increase the number of patients
1 Professora-associada, livre-docente em Clínica Médica, chefe do Laboratório de Genética Molecular do Câncer, Faculdade de Ciências Médicas (FCM), Universidade Estadual de Campinas (Unicamp), Campinas, SP, Brazil

Correspondence to: Laura Sterian Ward

Laboratório de Genética Molecular do Câncer, FCM/Unicamp Caixa Postal 6111

13083-970 - Campinas, SP, Brasil ward@fcm.unicamp.br 
treated with the author's protocol and it is necessary to study its application in different cities and by other groups or services that treat thyroid cancer patients, in order to confirm its larger feasibility in Brazil, this first report provides compelling evidences on the safety of high-dose administration on an outpatient basis.

The safety of the dose administration differs from country to country, according to the local interpretation of the International Atomic Energy Agency (IAEA) recommendations. The cornerstone criteria are dose limits for the public and dose constraints for relatives and caregivers. Different measures have been adopted, according to the International Basic Safety Standards (BSS), in the construal of maximum activity allowed for patients and caregivers in different countries and even in hospitals from the same country. A series of recent publications have reported actual measurements and external dose rates, as well as contamination potential that indicates that most countries are overly restrictive (3-7). Using a mathematical model, Coover and cols. (8) developed charts that took occupancy factors into account. The results indicate that most outpatients undergoing RIT for thyroid cancer may be safely treated with $7400 \mathrm{MBq}(200 \mathrm{mCi})$ or more (8). A recent simulation study published by a Brazilian group, which used the Visual Monte Carlo radiation transport code and the female voxel phantom to calculate organ and effective irradiation doses delivered by RIT also concluded for the safety of a $300 \mathrm{mCi}(11100 \mathrm{MBq})$ dose to a patient receiving daily care at home (9).

The Nuclear Regulatory Commission revised the criteria for RIT in the United States in 1997 and, theoretically, allowed patients requiring doses as high as $9,250 \mathrm{MBq}(250 \mathrm{mCi})$ to be discharged from the hospital immediately after receiving the radioiodine dose (10). Currently, in Europe, in the United States and in some Latin American countries, such as Argentina, competent and cooperative patients are routinely discharged with activities as high as $8000 \mathrm{MBq}(216 \mathrm{mCi})$, provided that they abide certain restrictions. The current dose constraints proposed in a number of publications include: children and fetuses, $1 \mathrm{mSv}$; adults up to 60 years of age, $3 \mathrm{mSv}$; adults over 60 years of age, $15 \mathrm{mSv}$; third persons, such as drivers of vehicles used for patient transport or general public, $0.3 \mathrm{mSv}$.

Sapienza and cols. (2) add data to previous reports on the safety, cost-effectiveness and patient acceptance of high dose ${ }^{131}$ I therapy delivered on an outpatient ba- sis (5-7). The levels of contamination were lower than regulatory limits. Patients and caregivers had no difficulty complying with requirements for radiation safety. Concerns about persons who provide direct care to the patient actually following regulations will always exist, but these results suggest that, for a well-selected and screened group of thyroid cancer patients receiving outpatient RIT, the procedure is safe and does not subject any family member or member of the public to the risk of exceeding accepted limits for public exposure to radiation.

The implication of the study is the urgent need for revision of our public policies and the prompt implementation of larger outpatient RIT protocols throughout the country. This should make the therapy more convenient and widely available, as well as reduce patient care costs.

Disclosure: No potential conflict of interest relevant to this article was reported.

\section{REFERENCES}

1. Maia AL, Ward LS, Carvalho GA, Graf H, Maciel RM, Maciel LM, et al. [Thyroid nodules and differentiated thyroid cancer: Brazilian consensus]. Arq Bras Endocrinol. Metabol. 2007;51(5):867-93.

2. Sapienza MT, Willegaignon J, Ono CR, Watanabe T, Guimarães MICC, Gutterres RF, et al. Radioiodoterapia do carcinoma diferenciado da tireoide: impacto radiológico da liberação hospitalar de pacientes com atividades entre 100 e $150 \mathrm{mCi}$ de iodo-131. Arq Bras Endocrinol. Metabol. 2007;53(3):318-25.

3. Rosenstein M. Diagnostic reference levels for medical exposure of patients: ICRP guidance and related ICRU quantities. Health Phys. 2008;95(5):528-34.

4. Gates VL, Carey JE, Siegel JA, Kaminski MS, Wahl RL. Nonmyeloablative iodine-131 anti-B1 radioimmunotherapy as outpatient therapy. J Nucl Med. 1998;39(7):1230-6.

5. Barrington SF, Anderson P, Kettle AG, Gadd R, Thomson WH, Batchelor $S$, et al. Measurement of the internal dose to families of outpatients treated with 131 I for hyperthyroidism. Eur J Nucl Med Mol Imaging. 2008;35(11):2097-104.

6. Panzegrau B, Gordon L, Goudy GH. Outpatient therapeutic 131। for thyroid cancer. J Nucl Med Technol. 2005;33(1):28-30.

7. Marriott CJ, Webber CE, Gulenchyn KY. Radiation exposure for 'caregivers' during high-dose outpatient radioiodine therapy. Radiat Prot Dosimetry. 2007;123(1):62-7.

8. Coover LR, Silberstein EB, Kuhn PJ, Graves MW. Therapeutic 131 in outpatients: a simplified method conforming to the Code of Federal Regulations, title 10, part 35.75. J Nucl Med. 2000;41(11):1868-75.

9. de Carvalho AB Jr, Hunt J, Silva AX, Garcia F. Use of a Voxel Phantom as a Source and a Second Voxel Phantom as a Target to Calculate Effective Doses in Individuals Exposed to Patients Treated with 1311. J Nucl Med Technol. 2009;37(1):53-6.

10. The Code of Federal Regulations: title 10, energy; part 35, section 75, release of individuals containing radiopharmaceuticals or permanent implants. Fed Regist. 1997;62:4120-33. 